\title{
A cheese sandwich never tasted better : 13 years in the life of Aaron Swartz (1999-2013)
}

\author{
Camille Akmut
}

October 10, 2021

(Un article a la Rene Taton.) 


\section{Introduction}

Going through existence without lasting guiding principles condemns individuals to a life spent as "half birds and fishes", as Pascal - this moralist of the 17th century - put.

Nietzsche, writing in the wake of the industrial revolution, observed that moralists had disappeared in societies where increased speeds and rhythms of life left no space in the minds of people for contrarians. (He included academics in this category, comparing them to anxious peasants.)

We live in the best of all worlds, we are constantly reminded.

Aaron Swartz's life and death should give us an indication, or an intuition that this is unlikely to be the case.

The sociologist Pierre Bourdieu called attempts to normalize and explain away everyday life, no matter how cruel painful or unjust, "social theodicies" referencing the long-standing problem of the justification of God in the presence of evil in the world, in the philosophical tradition. ${ }^{1}$ Justifications for inequalities are among them.

Marx had described the phenomenon as attempts to pass economics for natural causes, disasters.

Property rights have reached such a saintly status in our political systems that competing notions of human rights, even the most basic ones - housing, health, education... - everywhere take a backseat.

" Respect property, because it is the first law of societies.", invoked already a representative in the French revolution, who at least defended class interests openly. $^{2}$

The fate of the Gracchus brothers precedes him : dare touch property and never touch anything again.

Elites do not mind playing the game of "democracy", so long as it goes their way :

In the case of Allende, the local Chilean and international Bourgeois counterrevolution created improbable progressive movements (Feminine Power, combining feminism with [far-]right women), staged false strikes (affecting the key area of transportation), withheld basic foods (community initiatives were started to replace petty shop owners), harassed factory workers (solidarity networks connecting the various factories emerged), until their patience ran out and they called the army in, finally showing their true colors, firing at youths and students and random passerbys, killing journalists, presidents, anyone and everyone standing in their way... They were so unhinged at that point that they did it in front of rolling cameras - while striking poses. ${ }^{3}$

\footnotetext{
${ }^{1}$ See Leibniz' Theodicee as a famous example of these tortured arguments (leading to the almost comical "best of all worlds" theory).

${ }^{2}$ A quote attributed to the deputy Jean Desvars (cf. Popkin 2021).

${ }^{3}$ See Guzman's extraordinary documentary, The Battle of Chile.
} 
Gibson's Neuromancer describes a highly advanced stage of the capitalist system. In its opening pages he tells of people reduced to round-the-clock hustlers, who "one day" simply disappear as soon as unable, too weak to keep up with the latest demands of modern society.

Existing power structures are maintained by impersonal, interchangeable executives that are implanted with the entire histories of the giant corporations they serve, securing continuity beyond individuality and previously fixed biological barriers. Assassination attempts are vain. A manager is killed, another appears with no loss of information after an update.

Bio-technologies have extended the notion of property rights to now include the human body.

A home movie titled 'Cooking with Aaron' (2002) gives a rare insight into his early life : books everywhere, multiple computers including what appears to be an Apple, and a large comfortable house...

Aaron Swartz himself later wrote of his background, with no illusions :

"Undoubtedly, the first step is to choose the right genes: I was born white, male, American. My family was fairly well-off and my father worked in the computer industry." 4

(as part of a talk meant to be given at a conference in India?)

At a memorial, his father started speaking by relating the following, representative, anecdote :

"Growing up, Aaron's grandfather used to talk about the giant [?] library in Chicago. It was a public, technical library, which he spent a lot of time doing research [in] (...) He taught me how to use a library (...) [he] showed how libraries were magic portals into the knowledge of the world. Years later, when Aaron was young, the [?] library had moved to the University of Chicago (...) the $U$ of $C$ had tried to limit access (...) I took Aaron (...) to show him what a wonderful place the library was. I remember clearly pulling out a book off the shelf, which turned how to be from the 1800s, expressing how marvelous this was. (...)" 5

Finally, one of his friends observed :

"He moved in and out of institutions, he didn't fit into boxes (...) He was monk-like." 6

\footnotetext{
${ }^{4}$ Swartz 2007

${ }^{5}$ Robert Swartz 2013. (our transcript, in particular we were unable to identify which library was meant.)

${ }^{6}$ Ben Wikler (Day 2013).
} 
The years from 2000 onward cover Aaron's first experiences with activism (education reform), his first major achievements (the RSS 1.0 specfication), through PACER hacking all the way to "a really good grilled cheese sandwich"...

His early experiments with trying to transform the systems he found unpleasant or unjust in his immediate life surroundings (his own school) would be a framework or jump-start for the rest.

"Once I questioned the school I was in, I questioned the society that built the school" 7

In retrospect, there is a terrible consistency to Aaron's life, his general attitude and his overall interests and priorities staying mostly the same.

He did what all smart people end up doing, eventually : he drew all the consequences that could be drawn from his knowledge and started living life accordingly.

His example, and memory, should be a constant irritation to strategically apolitical individuals, to powerful ones because there are only very rich people where there are poor masses (no 'clean' fortunes), and to all the rest.

At age 13, in uncomfortably mature and disarmingly open writings, he wondered already "Who am I and what am I doing here" 8 .

A review of Aaron's life would not be complete without mention of what is perhaps his most striking blog post, "A Moment Before Dying", which appears to be a pseudonymous autobiography about

"a family of bellowing, rotund Americans, who had a room in their house with wall-to-wall, floor-to-ceiling cabinets, all entirely filled with bags and boxes"...

and a boy growing up with "body image issues" who later finds out that his problem is not immutable.

(We find here the same lifelong ethos of an issue being identified followed by a quest for a solution, which characterized much of Aaron's doing.)

This piece of writing underwent multiple modifications online, first appearing in its original form ${ }^{9}$, then erased (ie. replaced with the below notice), then restored but made to appear as if coming from a hypothetical third point of view :

"I'm OK, just have a bit of a cold. Sorry if the previous post here misled you. Thanks for the support."

\footnotetext{
${ }^{7}$ Swartz 2010.

${ }^{8}$ From one of the schoolyard subversions pages.

${ }^{9}$ Per the Rolling Stone article "The brillant life", though we could not find any archived versions of it
} 
(as captured by archive.org on January 29, 2007) ${ }^{10}$

In Aaron's last known or extent blog post, from 2012. the topic of suicide is renewed. Its last sentence (a discussion of the latest Batman movie) :

"Thus Master Wayne is left without solutions. Out of options, it's no wonder the series ends with his staged suicide."

Two other blog posts strike as outstanding : the twin series from September 2009 about the ethics of (friends) breaking in at MIT for food and shelter. Aaron goes :

"Even if they were costing MIT money, it seems this could be justified. MIT receives enormous sums from the wealthy and powerful, more than they know how to spend. Much of it gets spent on unneeded luxuries for their already-elite students. Redistributing it to the town's poorer residents seems potentially justified."

Extrapolate to academic articles, their privileged university subscribers and the needs of the rest of humanity, the world... and one gets closer to answering the open question of 'why he did it'.

But, that question is in fact of relative little value, being mostly now only of interests to historians and, coming before them, prosecutors. Of greater interest is the one that Aaron himself asked in the opening lines of those writings :

"How are we to live? Most people seem to agree that there are "right" things and "wrong" things and we should try to do the right ones, but they're less clear on how to figure out what the right ones are."

In The Long Tomorrow, Moebius imagined a civilization of the future characterized by vast vertical constructions where the social order was such rich residents occupied, counter-intuitively, the lower levels without providing much explanation. [We suspect it must be something to do with the environment...]

In today's urban centres, life is only possible at the cost of a great, constant mental strain : looking away.

But, capitalism's effects eventually catch up with everyone as the strident laughs of today are replaced by the bitter tears of tomorrow...

\footnotetext{
${ }^{10}$ See also "Life in sururbia" (" the fake coat of paint that lets you pretend your unhappy life is just as nice as everyone else's") and "Eat and code" ("I've always had a problematic relationship with food.") for more.
} 


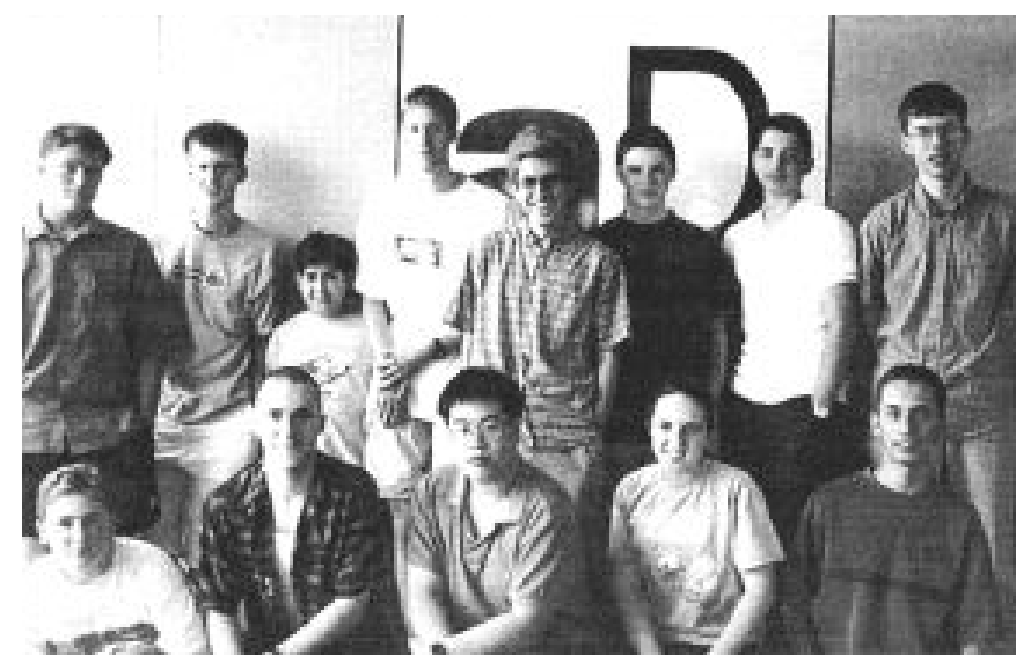

\begin{tabular}{|c|c|c|}
\hline & Student at North Shore Country Day School. & $\begin{array}{c}\text { Swartz } \\
2000 \mathrm{~b}\end{array}$ \\
\hline \multicolumn{3}{|c|}{1999} \\
\hline until 2000 & "Member" RDF Core Working Group & $\begin{array}{l}\text { LinkedIn via } \\
\text { FBI File }\end{array}$ \\
\hline until 2000 & "Member" W3C & $\begin{array}{l}\text { LinkedIn via } \\
\text { FBI File }\end{array}$ \\
\hline \multicolumn{3}{|c|}{2000} \\
\hline May - June & $\begin{array}{l}\text { 13, Aaron launches 'The Info Network', becomes a finalist } \\
\text { ("runner-up") for the ArsDigita prize which includes a trip to } \\
\text { MIT. The Boston Herald describes the creation as "a Web site } \\
\text { designed to contain all human knowledge."... }\end{array}$ & $\begin{array}{l}\text { Swartz 2000; } \\
\text { Schorow } \\
2000 ; \text { Swartz } \\
2006 \mathrm{~g}\end{array}$ \\
\hline $\begin{array}{l}\text { Summer } \\
\text { (August?) }\end{array}$ & $\begin{array}{l}\text { Ninth-grader, starts a blog collecting his experiences with school } \\
\text { and shares alternative resources (unschooling, Holt, Paulo Freire, } \\
\text { Sudbury etc.) "I finally realized that school wasn't working [and] } \\
\text { decided to do something about it." eg. "fight to change my school." }\end{array}$ & $\begin{array}{l}\text { Swartz } \\
2000 \mathrm{~b}\end{array}$ \\
\hline Dec. 6 & Release of the RSS (RDF Site Summary) 1.0 specification. & $\begin{array}{l}\text { Swartz via } \\
\text { resource.org; } \\
\text { TIOB }\end{array}$ \\
\hline \multicolumn{3}{|c|}{2001} \\
\hline April & $\begin{array}{l}\text { Dubbed "Teenager in a million" in the press for his work on In- } \\
\text { ternet standards (RFCs) and meeting Tim Berners-Lee }\end{array}$ & $\begin{array}{l}\text { O'Brien } \\
2001\end{array}$ \\
\hline
\end{tabular}


Sept. (?) "After a year of high school he found it intolerable and refused to go back. His family told the state of Illinois that they were "homeschooling" him and he enrolled in a handful classes at nearby Lake Forest College (Physics, Chemistry, Logic, and Number Theory) but spent most of his time on his own."

\begin{tabular}{|c|c|c|}
\hline \multicolumn{3}{|c|}{2002} \\
\hline Until 2004 & "Metadata Advisor" at Creative Commons & $\begin{array}{l}\text { LinkedIn via } \\
\text { FBI File }\end{array}$ \\
\hline Aug. & Aaron reviews the Eldred v. Ashcroft case in a blog post & $\begin{array}{l}\text { Swartz } \\
2002 b\end{array}$ \\
\hline Oct. & $\begin{array}{l}\text { Travels to Washington, D.C.. "I met Aaron at the U.S. Supreme } \\
\text { Court (...) when we both went to hear the oral argument in Eldred } \\
\text { v. Ashcroft. Most of us non-lawyers had to spend the night } \\
\text { sleeping in the street in front of the Court in order to get a ticket } \\
\text { - since the line to get into an oral argument generally starts } \\
\text { forming the night before - but Aaron (though a teenager) was } \\
\text { Larry Lessig's personal guest" }\end{array}$ & $\begin{array}{l}\text { Schoen } \\
\text { 2013b; see } \\
\text { also Clark } \\
2014\end{array}$ \\
\hline \multicolumn{3}{|c|}{2004} \\
\hline Sep. onward & $\begin{array}{l}\text { Aaron goes to Stanford and hates it - giving way to an epic, 16- } \\
\text { some part takedown [the Disneyland of higher ed.]. "There is } \\
\text { a large career fair today, with booths for all sorts of companies. } \\
\text { Already, we are being pointed towards careers." Sociology. }\end{array}$ & $\begin{array}{l}\text { Swartz 2004; } \\
\text { LinkedIn via } \\
\text { FBI File }\end{array}$ \\
\hline \multicolumn{3}{|c|}{2005} \\
\hline & Y Combinator, Paul Graham & TIOB \\
\hline $\begin{array}{l}\text { circa June } \\
\text { onward }\end{array}$ & Moves to Simmons Hall (Cambridge) & $\begin{array}{l}\text { Swartz } \\
2006 \mathrm{~h}\end{array}$ \\
\hline $\begin{array}{l}\text { Nov. (until } \\
\text { Jan. 2007) }\end{array}$ & $\begin{array}{l}\text { "co-founder" reddit. " in short, last November I joined the amazing } \\
\text { team behind reddit, merging our two companies." (in Swartz } 2006 \mathrm{~g} \\
\text { October is mentioned) }\end{array}$ & $\begin{array}{l}\text { LinkedIn via } \\
\text { FBI File; } \\
\text { Swartz } 2006 \mathrm{f}\end{array}$ \\
\hline \multicolumn{3}{|c|}{2006} \\
\hline & $\begin{array}{l}\text { Lives in San Francisco with Peter Eckersley (EFF employee) in a } \\
\text { sharehouse, in the tiniest, closet-sized room }\end{array}$ & $\begin{array}{l}\text { Eckersley } \\
\text { 2013; also } \\
\text { TIOB }\end{array}$ \\
\hline May 27 & $\begin{array}{l}\text { Comes to the conclusion that being a writer is more important for } \\
\text { him than being a programmer. "writing code, although it can be } \\
\text { enjoyable, is hardly something I want to spend my life doing." }\end{array}$ & $\begin{array}{l}\text { Swartz } \\
2006 \mathrm{~d}\end{array}$ \\
\hline
\end{tabular}


circa July Visiting a friend at MIT makes Aaron further reconsider life

Swartz choices. "Perhaps it's natural, when doing something so greedy and practical as a startup, to pine for the idealized world of academia. (...) It's not that I don't enjoy my work; it's just that I feel like I'm getting dumber doing it."

\begin{tabular}{|c|c|c|}
\hline Oct. 2006 & Reddit is purchased by Conde Nast & $\begin{array}{l}\text { Swartz } \\
2006 \mathrm{~g}\end{array}$ \\
\hline $\begin{array}{l}\text { circa Novem- } \\
\text { ber }\end{array}$ & $\begin{array}{l}\text { Crisis. "Since I moved to San Francisco I literally haven't gotten } \\
\text { anything done. I haven't finished a book (..), I haven't answered } \\
\text { many emails (...), I've written only a couple blog posts (I used } \\
\text { to do one a day), and I haven't written a line of code (I used } \\
\text { to write whole programs in the evenings). It's a pretty incredible } \\
\text { state of affairs.", "By lunch time I had literally locked myself in a } \\
\text { bathroom stall and started crying." }\end{array}$ & $\begin{array}{l}\text { Swartz } \\
2006 c\end{array}$ \\
\hline \multirow[t]{2}{*}{ circa Dec. } & $\begin{array}{l}\text { Trip overseas; prompts a devastating blog post, 'Cultural Impe- } \\
\text { rialism Sucks' : " Berlin does not feel like a particularly vibrant } \\
\text { city.", "One wonders how much of their fitting in is an attempt to } \\
\text { forget their different past." ... The 23c3 is the object of a separate } \\
\text { entry wherein Aaron declares "I don't particularly like comput- } \\
\text { ers"; accompanied by Seth Schoen. }\end{array}$ & $\begin{array}{l}\text { Swartz } 2006 \\
\text { and } 2007 \mathrm{c} ; \\
\text { Schoen } 2013\end{array}$ \\
\hline & $\begin{array}{l}\text { Launch of "pilot project }(\ldots) \text { to provide free PACER access to } \\
\text { users at } 17 \text { libraries around the country" }\end{array}$ & Lee 2013 \\
\hline $\begin{array}{l}\text { until at least } \\
\text { Feb. } 2009\end{array}$ & $\begin{array}{l}\text { "Tech Lead" at Open Library. "The idea is to be a huge wiki, an } \\
\text { editable website, with one page per book. So for every book ever } \\
\text { published, we want to have a webpage about it (...)" }\end{array}$ & $\begin{array}{l}\text { LinkedIn via } \\
\text { FBI File; } \\
\text { Swartz via } \\
\text { TIOB }\end{array}$ \\
\hline Jan. 2007 & End of "co-founder" reddit period after 1 year and 3 months & $\begin{array}{l}\text { LinkedIn via } \\
\text { FBI File }\end{array}$ \\
\hline Jan. 18 & $\begin{array}{l}\text { Stomach issues(?). "one week of pain (...) searing, tormenting } \\
\text { agony" ('A Moment Before Dying' blog post) }\end{array}$ & $\begin{array}{l}\text { Swartz } \\
\text { 2007b (for } \\
\text { compar. } \\
\text { S.-K. 2013) }\end{array}$ \\
\hline $\begin{array}{l}\text { until at least } \\
\text { Feb. } 2009\end{array}$ & "Founder" watchdog.net & $\begin{array}{l}\text { LinkedIn via } \\
\text { FBI File }\end{array}$ \\
\hline Jul. & $\begin{array}{l}\text { "EIFL meeting at a monastery in Italy" Quinn Norton is also in } \\
\text { attendance }\end{array}$ & Norton 2013 \\
\hline
\end{tabular}




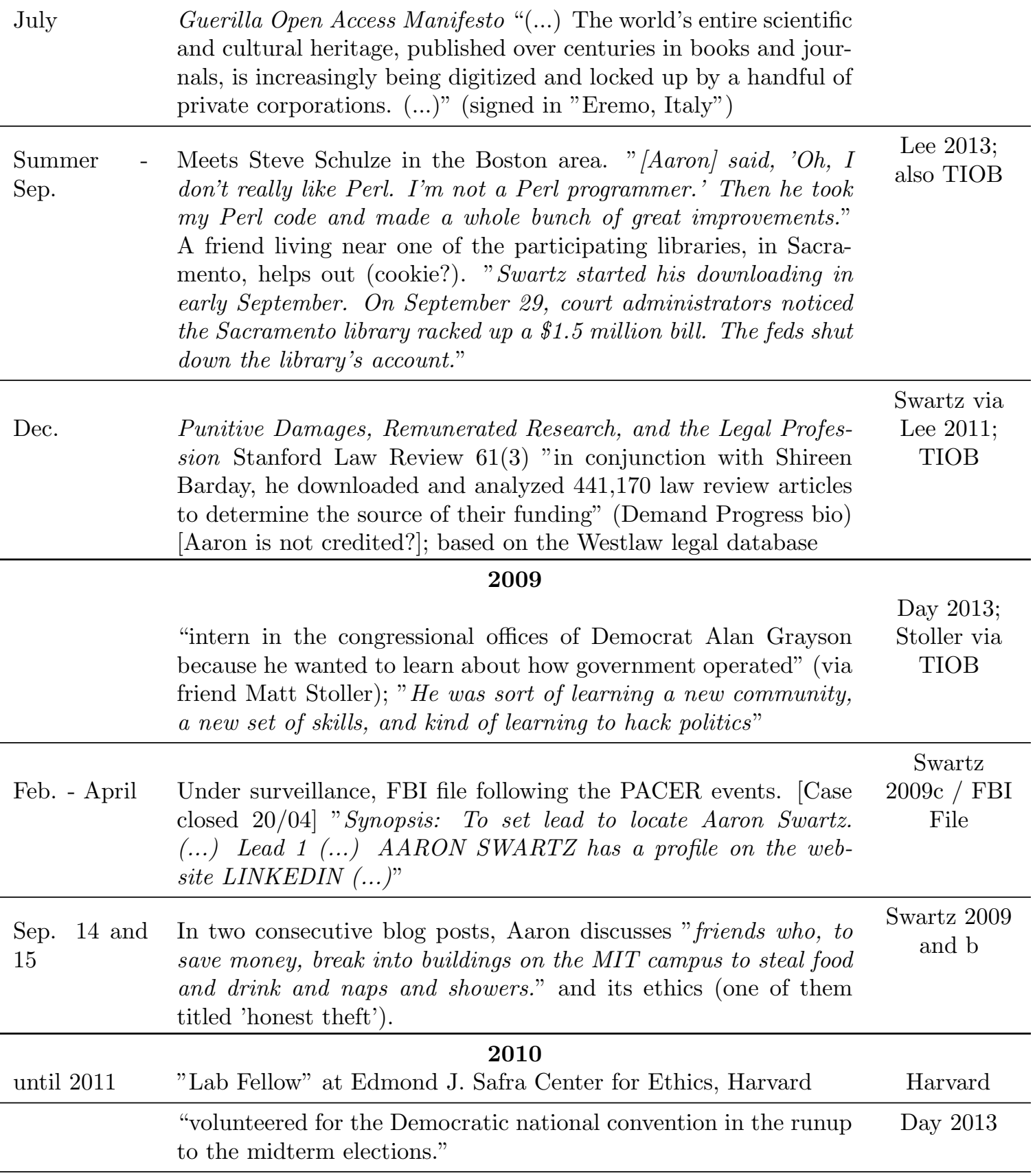


Sep. Learns about COICA, the Combating Online Infringement and Counterfeits Act, which morphed into SOPA ("from [his] friend

Peter"... Eckersley?). "this bill would let the government devise a list of websites that Americans weren't allowed to visit"

\begin{tabular}{|c|c|c|}
\hline Sep. 24 & $\begin{array}{l}\text { "registered his computer on MIT's campus and obtained a guest } \\
\text { account on MIT's computer network. The individual did not pro- } \\
\text { vide his true identity at this or any subsequent time" }\end{array}$ & $\begin{array}{l}\text { USA v. } \\
\text { Swartz }\end{array}$ \\
\hline Sep. 25 & "hundreds of thousands of downloads from the ghost laptop" & $\begin{array}{l}\text { USA v. } \\
\text { Swartz }\end{array}$ \\
\hline Sep. 26 & $\begin{array}{l}\text { "The next day (...) the ghost laptop's user obtained a new IP ad- } \\
\text { dress from MIT's network (...) This defeated JSTOR's IP address } \\
\text { block" }\end{array}$ & $\begin{array}{l}\text { USA v. } \\
\text { Swartz }\end{array}$ \\
\hline Oct. 2 & $\begin{array}{l}\text { "Having recognized that MIT or JSTOR had blocked his ghost lap- } \\
\text { top by recognizing its } M A C \text { address, the individual now manipu- } \\
\text { lated the ghost laptop's MAC address to mislead MIT into believing } \\
\text { that he was a new and different guest registrant." }\end{array}$ & $\begin{array}{l}\text { USA v. } \\
\text { Swartz }\end{array}$ \\
\hline Oct. $8(?)$ & $\begin{array}{l}\text { " connected a second computer to MIT's network and created an- } \\
\text { other guest account" }\end{array}$ & $\begin{array}{l}\text { USA v. } \\
\text { Swartz }\end{array}$ \\
\hline Oct. 9 & $\begin{array}{l}\text { "activated the ghost laptop and the ghost macbook to download } \\
\text { JSTOR's articles once again." }\end{array}$ & $\begin{array}{l}\text { USA v. } \\
\text { Swartz }\end{array}$ \\
\hline Oct. 16 & $\begin{array}{l}\text { Gives a talk about the (unequal) accessibility of scholarly journals, } \\
\text { at the Univ. of Illinois. Mentions JSTOR, among other providers. } \\
\text { "It's a legacy that should belong to us, as a commons, as a people. } \\
\text { But, instead it's been locked up (...) by a handful of for-profit } \\
\text { corporations" }\end{array}$ & $\begin{array}{l}\text { Swartz via } \\
\text { TIOB }\end{array}$ \\
\hline $\begin{array}{l}\text { End of Oct. - } \\
\text { Jan. } 62011\end{array}$ & $\begin{array}{l}\text { "the hacker obtained at least three new IP addresses and assigned } \\
\text { his computer two new MAC addresses. He also moderated the } \\
\text { speed of the downloads, which made them less noticeable to JS- } \\
\text { TOR." }\end{array}$ & $\begin{array}{l}\text { USA v. } \\
\text { Swartz }\end{array}$ \\
\hline
\end{tabular}


Jan. 4 to a network switch located in a basement wiring closet in MIT's

\begin{tabular}{|c|c|c|}
\hline $\begin{array}{l}\text { mid-day Jan. } \\
4\end{array}$ & $\begin{array}{l}\text { "Experience told them that (...) rather than take the hacker's } \\
\text { equipment away (...) The ruse worked. Within an hour of their } \\
\text { departure, the hacker returned." }\end{array}$ & $\begin{array}{l}\text { USA v. } \\
\text { Swartz }\end{array}$ \\
\hline Jan. 6 & $\begin{array}{l}\text { "the hacker returned to the wiring closet yet again. This time, } \\
\text { worried about being identified, the hacker covered his face with his } \\
\text { bicycle helmet as he entered the closet. (...) A little after 2:00 that } \\
\text { afternoon, MIT Police Captain (...), who had been involved in the } \\
\text { investigation, was heading down Massachusetts Avenue within a } \\
\text { mile of MIT when he spotted a bicycler who looked like the hacker } \\
\text { caught on the wiring closet video. Captain (...) identified himself } \\
\text { as a police officer. After a brief exchange, the individual dropped } \\
\text { his bike to the ground and ran away. The individual was chased, } \\
\text { apprehended, arrested, and identified" }\end{array}$ & $\begin{array}{l}\text { USA v. } \\
\text { Swartz }\end{array}$ \\
\hline Jan. 6 & $\begin{array}{l}\text { "I had to get a hold of [his] lawyer and find someone to bail him } \\
\text { out. I found a local friend, who went and got out } \$ 1,000 "\end{array}$ & Norton 2013 \\
\hline Feb. & $\begin{array}{l}\text { "(...) the inevitable raid. The Secret Service came to his house } \\
\text { and his office at the Harvard Ethics Center and took hard drives } \\
\text { and computers. Aaron's phone was taken." }\end{array}$ & Norton 2013 \\
\hline End of April & $\begin{array}{l}\text { "Aaron, Ada, and I went to DC, and took Ada to the museums. } \\
\text { We walked along the sidewalk in front of the White House to- } \\
\text { gether. Aaron looked past the lawns at the grand doors and said } \\
\text { quietly "They don't let felons work there." I replied it was ironic, } \\
\text { given how many felonies were committed there. But Aaron didn't } \\
\text { laugh." }\end{array}$ & Norton 2013 \\
\hline "Summer" & $\begin{array}{l}\text { "we didn't trust each other anymore (...) He wanted something } \\
\text { untouched by all of this, and had met someone - someone more } \\
\text { like who he wanted to be. (...) he told me our relationship had to } \\
\text { stop." }\end{array}$ & Norton 2013 \\
\hline June & Beginning of relationship with Taren Stinebrickner-Kauffman. & Collins 2013 \\
\hline
\end{tabular}

"an MIT network security analyst traced the hacker's IP address Building 16. (...) When MIT personnel entered the closet, they found (...) the ghost laptop, an Acer-brand laptop, connected to a separate hard drive for excess storage. (Ex. 11). The network cable connected the laptop to the network switch, thus giving the laptop Internet access. (...) MIT called campus police to the scene, who, in turn, brought in the Cambridge Police and the Secret Service. (...) The Secret Service opened the laptop and sought to make a copy of its volatile memory (RAM) (...)" etc. etc.

USA v. Swartz

USA $\mathrm{v}$.

" the hacker returned to the wiring closet yet again. This time, afternoon, MIT Police Captain (...), who had been involved in the investigation, was heading down Massachusetts Avenue within a mile of MIT when he spotted a bicycler who looked like the hacker caught on the wiring closet video. Captain (...) identified himself apprehended, arrested, and identified" out. I found a local friend, who went and got out $\$ 1,000$ " and his office at the Harvard Ethics Center and took hard drives and computers. Aaron's phone was taken." We walked along the sidewalk in front of the White House together. Aaron looked past the lawns at the grand doors and said quietly "They don't let felons work there." I replied it was ironic, given how many felonies were committed there. But Aaron didn't laugh." like who he wanted to be. (...) he told me our relationship had to stop."

\section{2}


May

Delivers "How we stopped SOPA" keynote speech at the F2C

Nov. 1 Last known/extent blog post. " The Dark Knight Rises 1980s-style Swartz 2012 tough-on-crime policies and neoliberal economics lead to a revolt"

"The last day I saw Aaron was two weeks before he died. (...)

Norton 2013

We'd become friends again, though slowly and imperfectly (...) I was dropping my daughter off to spend her Christmas break with Aaron and his girlfriend"

\section{3}

New Year Vacation. "We went to Burlington with a bunch of friends and stayed in a house and played in the snow. It was wonderful." Request for plea deal turned down.

Collins 2013

\begin{tabular}{ccc}
\hline Jan. 9 & Request for plea deal turned down. & Collins 2013 \\
\hline & (T. S.-K.)
\end{tabular}

Jan. $10 \quad$ Aaron eats a really good grilled cheese sandwhich. "The night before he died, Aaron really wanted to go to a bar called Spitzers Corner in the Lower East Side. I was tired and didn't want to but Collins 2013.

See also he insisted. He wanted to go to the Happy Hour (...)"

S.-K. 2013

$\begin{array}{ll}\text { Funeral } & \text { Robert Swartz reads a eulogy containing the following condemna- } \\ & \text { tion: "He was killed by the government and MIT betrayed all of }\end{array}$

Collins 2013

$\begin{array}{ll}\text { Funeral } & \text { Robert Swartz reads a eulogy containing the following condemna- } \\ & \text { tion : "He was killed by the government and MIT betrayed all of }\end{array}$ its basic principles."

Jan. 24 At a memorial, Taren Stinebrickner-Kauffman reiterates "Aaron's Malamud death should radicalize us", Carl Malamud speaks of "a posse in2013 tent on protecting property, not people." among others.

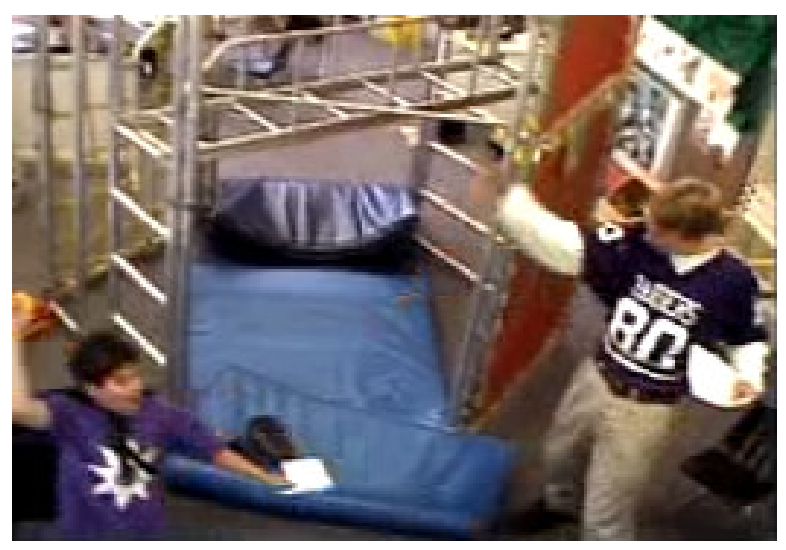




\section{Bibliography}

https://web.resource.org/rss/1.0/ ("This document is maintained by Aaron Swartz on behalf of the RSS-DEV (...)")

Swartz, Aaron. Var.. "Movies". http://www.aaronsw.com/movies/ (at least one movie gives an insight into his home life, "Cooking with Aaron: Fun with Ooblick", two school life...)

-. 2000. The Info Network. http://www.theinfo.org/

- 2000b. "background / The Story" in schoolyard subversion, 11/08. http: //swartzfam.com/aaron/school/about/ (includes, among others, a review of Pedagogy of the Oppressed)

- 2002b. "Government Responds in Eldred v. Ashcroft". 05/08. http: //www . aaronsw. com/weblog///000474

-. 2004. [Stanford series].

Day 1 http://www . aaronsw. com/weblog/001418

Day 16 http://www. aaronsw.com/weblog/001432

- 2005. "Eat and Code". Raw Thought blog, 02/08. www.aaronsw.com/ weblog/eatandcode (his liking of "plain", "white" foods (microwaved bagels, steamed rice...))

- 2006. "Cultural Imperialism Sucks: a visit to Berlin" Raw Thought blog, 27/12. http://www . aaronsw. com/weblog/cultimp

-. 2006b. "I Love the University" Raw Thought blog, 26/07. www.aaronsw . com/weblog/visitingmit

-. 2006c. "Office Space" Raw Thought blog, 15/11. http://www.aaronsw . com/weblog/officespace

-. 2006d. "A Non-Programmer's Apology" Raw Thought blog, 27/05. www . aaronsw.com/weblog/nonapology

- 2006e. "Life in Suburbia: Land of Cliche" Raw Thought blog, 16/06.

wWw . aaronsw. com/weblog/suburbia

—. 2006f. "Wassup?" Raw Thought blog, 27/03. www.aaronsw.com/weblog/ wassup

(on infogami and reddit)

—. 2006g. "a lifetime of dubious accomplishments". In : FBI File 
-. 2006h. "Stanford/SFP: Leaving on a Jet Plane" Raw Thought blog, 11/06. www . aaronsw. com/weblog/stanford2sfp

(see also "Simon Arrives")

-. 2007. "How to Get a Job Like Mine". https://aaronsw.jottit.com/ howtoget

—. 2007b. "A Moment Before Dying". Raw Thought blog, 18/01. www. aaronsw.com/weblog/dying

-. 2007c. "Berlin" Raw Thought blog, 30/01. http://www.aaronsw.com/ weblog/23c3 (on the Chaos Communications Congress)

-. 2009. "A Short Course in Ethics". Raw Thought blog, 14/09. http:

//www . aaronsw.com/weblog/ethics

-. 2009b. "Honest Theft". Raw Thought blog, 15/09. http://www. aaronsw. $\mathrm{com} / \mathrm{weblog} /$ honesttheft

-. 2009c. "Wanted by the FBI". Raw Thought blog, 05/10. www.aaronsw . $\mathrm{com} /$ weblog/fbifile

—. 2010. Interview with SpunOut.ie. "We Can Change The World"

-. 2012. "What Happens in The Dark Knight". Raw Thought blog, 01/11.

http: //www . aaronsw.com/weblog/tdk

-. 2012b. "How we stopped SOPA". Freedom to Connect conference (F2C)

(also given at ThoughtWorks on 16/08)

Amsden, David. 2013. "The Brilliant Life and Tragic Death of Aaron Swartz" Rolling Stone, 15/02.

Collins, Laura. 2013. "EXCLUSIVE - Last picture of tragic internet guru: Reddit founder's girlfriend tells of their last hours" MailOnline (Daily Mail), $17-18 / 01$.

Clark, Drew. 2014. "'On the Internet, No One Knows You're a Child': The Short Life of Aaron Swartz, at Sundance" Broadband Breakfast, 23/01. https:

//broadbandbreakfast.com/2014/01/on-the-internet-no-one-knows-youre-a-child-the-short-life

Day, Elizabeth. 2013. "Aaron Swartz: hacker, genius... martyr?" (Interview Taren Stinebrickner-Kauffman). The Guardian, 01/06. 
Eckersley, Peter. 2013. Memorial at the Internet Archive, 24/01.

Harvard. "Aaron Swartz". http://ethics.harvard.edu/people/show-bio/all/352?layout=showbio

Lee, Timothy. 2011. "Former Reddit co-owner arrested for excessive JSTOR downloads" Ars Technica, 19/07.

Lee, Timothy. 2013. "The inside story of Aaron Swartz's campaign to liberate court filings" Ars Technica, 08/02. (by one of the creators of RECAP. "In a recent phone interview, Schultze (...)"

Mass High Tech. 2000. "ArsDigita Foundation awards Net design prize to under-18 crowd" (includes a photo of Aaron, as shown above)

Malamud, Carl. 2013. Schoen, Seth. 2013. Memorial at the Internet Archive, $24 / 01$.

Norton, Quinn. 2013. "Life Inside the Aaron Swartz Investigation" The Atlantic, 04/03.

O’Brien, Danny. 2001. "Teenager in a million" Sunday Times, 29/04.

Schoen, Seth. 2013. Memorial at the Internet Archive, 24/01.

Schoen, Seth. 2013b. "How I Knew Aaron". 16/01. https://github.com/ rememberaaronsw/rememberaaronsw still accessible through Software heritage under /memories/_posts/ (appears to be the text of the memorial speech)

Schorow, Stephanie. 2000. "Contest showcases innovative Web sites by world's teens". Boston Herald, 01/06. http://www.bostonherald.com/lifestyle/ lifestyle_trends/net06132000.htm

Stinebrickner-Kauffman, Taren. 2013. "Why Aaron died". 04/02. https: //tarensk.tumblr.com/post/42260548767/why-aaron-died

Stinebrickner-Kauffman, Taren. 2013b. Memorial at the Internet Archive, $24 / 01$.

Swartz, Robert. 2013. MIT Media Lab memorial.

[TIOB] The Internet's Own Boy (2014)

Popkin, Jeremy. 2021. "The French Revolution Was the Beginning of the Modern World" Jacobin, 10/05. 


\section{Methodology and technical notes}

- Our leading principle was to seek out and reference primary sources whenever possible, ie. writings or other media by Aaron himself, his partners, friends, family... Legal and police documents were also considered.

- Among the goals of this project is to help others gain a succinct, dependable overview of Aaron's life (whatever their own goals). Its inspiration was the similar project undertaken by the historian of science Taton on Pascal in the 1960s.

- Aspects of Aaron's life, in particular technical details, were covered in several previous publications, "A brief history of Aaron Swartz on Github", the keepgrabbing.py articles, and the companions to the MIT/JSTOR case, among others.

The Perl script used for massively retrieving the PACER documents seems rudimentary but, (not only is it an early version of it), it relies on "the vulnerability of the PACER pilot project was that the cookie used for log-in did not track the user's IP address" per the FBI File ${ }^{11}$ e.g.,

* it did not need to be renewed with every download, * the downloading itself did not even need to take place at an authorized location, library but could happen from anywhere.

The program would be executed about like so :

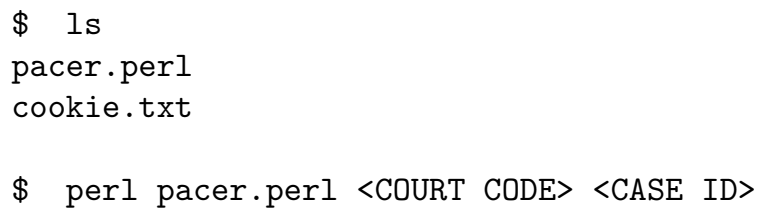

\footnotetext{
${ }^{11}$ The File goes on to specify that "The only limit in place was that the cookie lasted for one week." (ergo every week someone would need to grab the cookie from one of the PACER program participating libraries.)
} 


\section{Annex}

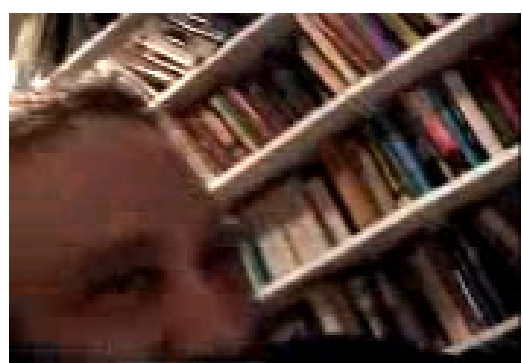

Figure 1: One of the bookshelves at the Swartz' (2002)

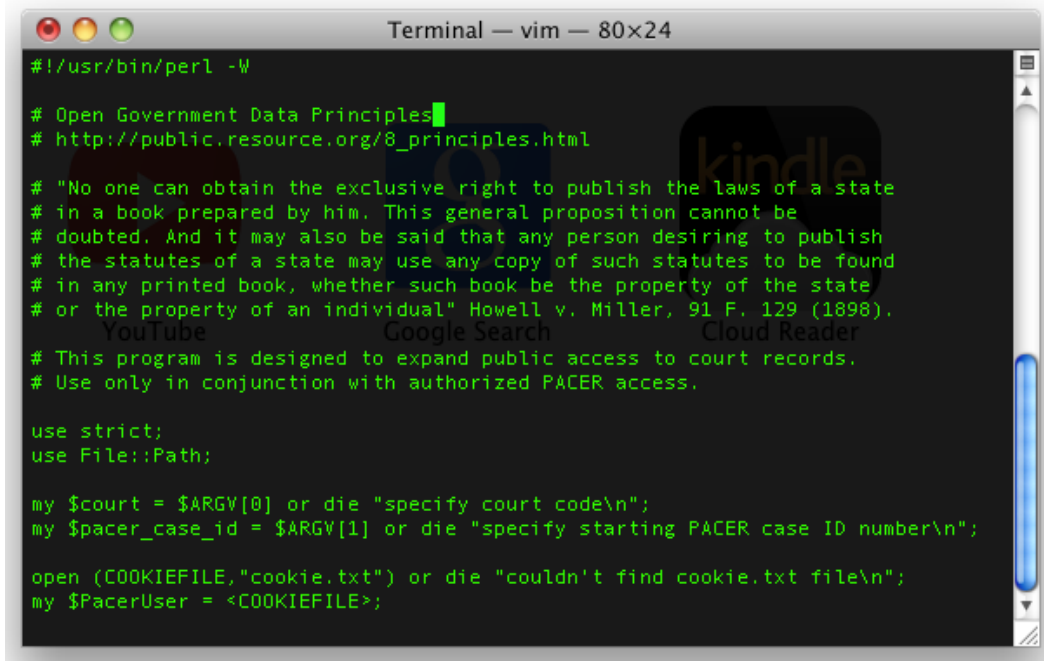

Figure 2: Schulze's perl script

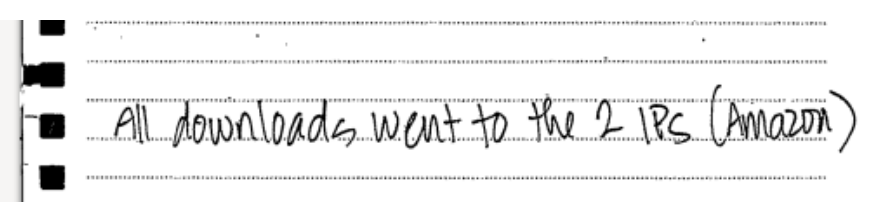

Figure 3: Extract from FBI File 


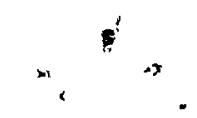

FD-302 (Rev. 10-6-95)

$-1-$

FEDERAL BUREAU OF INVESTIGATION

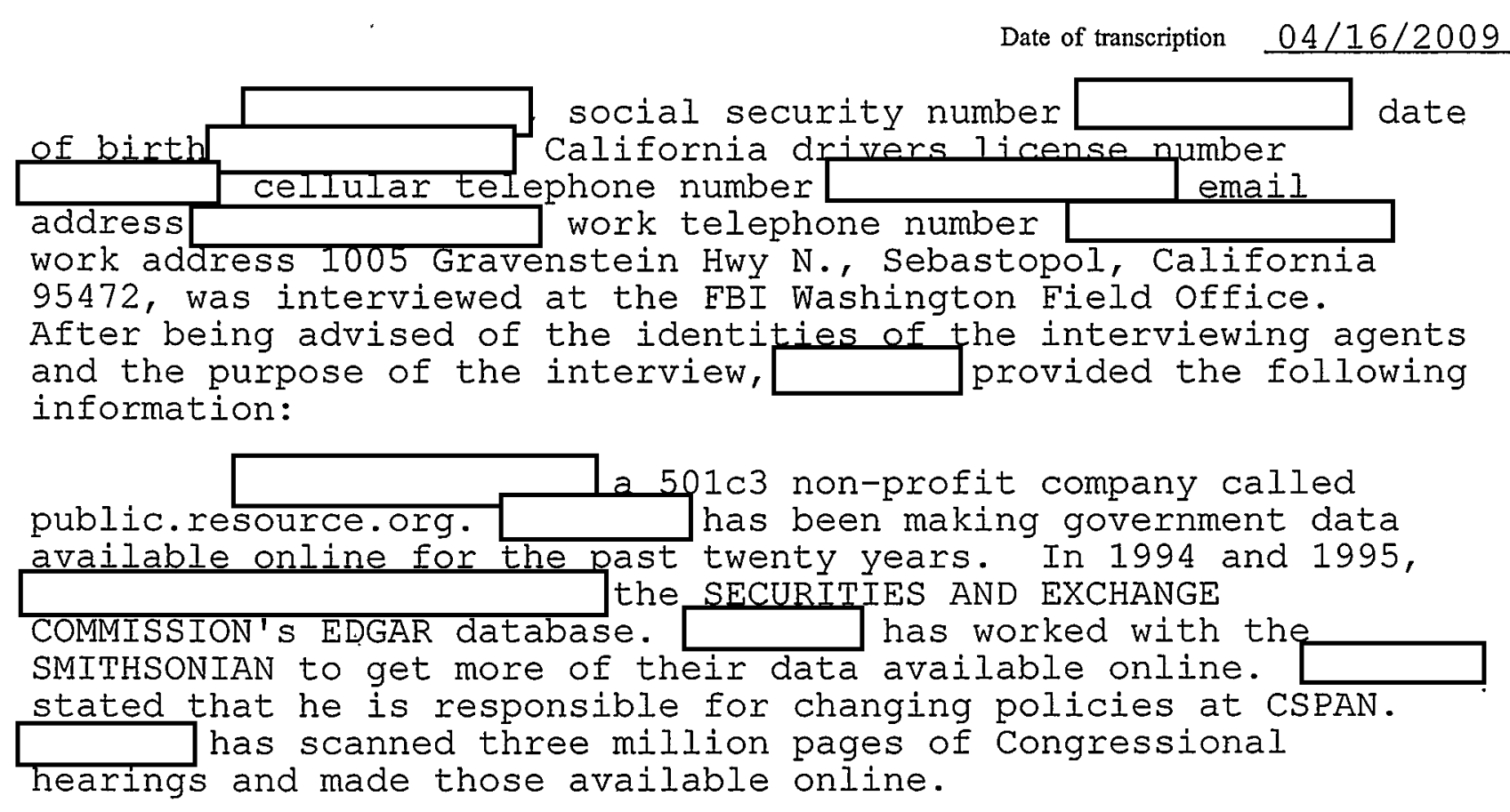

In 2007 ,

$\square$ began focusing

materials that needed attention. In 2008,

on orimary legal

years worth of COURT OF APPEAIS information online. People began writing with concern that their social security numbers were posted online in this data. Was able to get LEXUSNEXUS and WEST to redact social security numbers. sent an audit to Judge ROSENTHAL listing the social security numbers posted online and presented a series of recommendations for correcting this issue.

In mid-2008, pacer.resource.org. intended for this website to get policy aims across and
get PACER documents uploaded for anyone to view. not like the PACER pilot project and made this clear on his website in the seventeen frequently asked questions (FAO) FAQ number sixteen refers to a thumb drive corps where encourages people to go to the seventeen libraries participating in the PACER pilot project and download PACER documents. Then the PACFR documents can be uploaded as pdf documents on website using an upload button. $04 / 15 / 2009$ at Washington, DC

File \#288A-WF-238943-39.

SA

by $S A$

Date dictated $N / A$ 


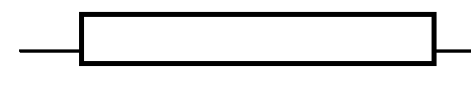
, On $/ 15 / 2009$ , Page 2

Although has a PACER account, retrieve the documents himself because other people are pavina for the documents and are allowed to redistribute them. assumed people who read his FAQ for the thumb drive corps would either obtain the documents by paying for them or go to one of the seventeen libraries and download the documents for free.

One volunteer, AARON SWARTZ, contacted in reference to the thumb drive corps and explained that he had 770 gigabytes of PACER data. gave SWARTZ an account at public.resource.org so that SWARTZ could upload all the data at once, instead of uploading each document using the upload button on the webpage. that it was clean. illegal and reviewed the data and was satisfied hackers. does not believe what SWARTZ did was percent $(20 \%)$ of all PACER documents. for social security numbers and found 1,700 documents that included social security numbers.

\section{SWARTZ is not employed by
pay SWARTZ to obtain the PACER documents. and} paid anyone for bulk PACER data. Users who uploaded PACER documents were never paid by SWART2's account at public.resource.org was terminated when discovered that the PACER pilot project had been cancelled.

physically in one of the seventeen libraries participating in the PACER pilot project to legitimately accesS PACER documents for free. SWARTZ downloaded PACER documents for approximately six weeks and no one for the ADMINISTRATIVE OFFICE OF THE US COURTS (US COURTS) made a statement regarding this activity. never saw any signs in the libraries that stated that the PACER documents were for personal use. If $\square$ had seen any indication of that, he would not have released the data but would have still completed the social security numbers audit. reviewed the security language and the announcement for the release of the PACER pilot project and did not see anything stating that a normal user could not access PACER documents in the way that he encouraged the thumb drive corps to do so.

saw the notice on the PACER log-in page prohibiting unauthorized access. not unauthorized access because the data was available for users 
$\therefore \quad$.

FD-302a (Rev. 10-6-95)

$288 \mathrm{~A}-\mathrm{WF}-238943$

Continuation ofFD-302 of

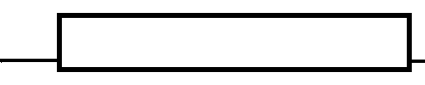
$0 \mathrm{n} A / 15 / 2009$ , Page 3

to view. studied this statement and consulted others to ensure that what he was asking the thumb drive corps to do was not unauthorized access.

did not have anyone else supplying large numbers of PACER documents like SWARTZ was able to upload. There were thousands of users uploading small numbers of documents. A total of 80,000 pages has been uploaded through pacer.resource.org. Users who uploaded documents were anonymous. did not check the uploaded pages until sometime later to determine if they were real PACER documents.

The vulnerability of the PACER pilot project was that the cookie used for log-in did not track the user's IP address. suggested that a remedy would be to prompt the user to log-in again if the cookie that was originally used to log-in was later used on a different computer with a different IP address. At the time the PACER pilot project was compromised, all a user had to do was log-in, then use that cookie on another computer to gain access to the PACER documents at a later time. The only limit in place was that the cookie lasted for one week.

contacted the US COURTS multiple times explaining that he would work with the US COURTS' technical staff to correct this problem, one contact occurring on october 23, 2008. Contacted the DEPARTMENT OF JUSTICE in Seattle, washington and explained to Assistant United States Attorney that social security numbers were being printed online. L was told that there was no investigation into this matter. Worked with Professor from CORNELI LAW SCHOOL. Through L and Volunteered to help the US CoURTS with their computer systems and redacting the social security numbers. COURTS has never contacted him. is frustrated that the US

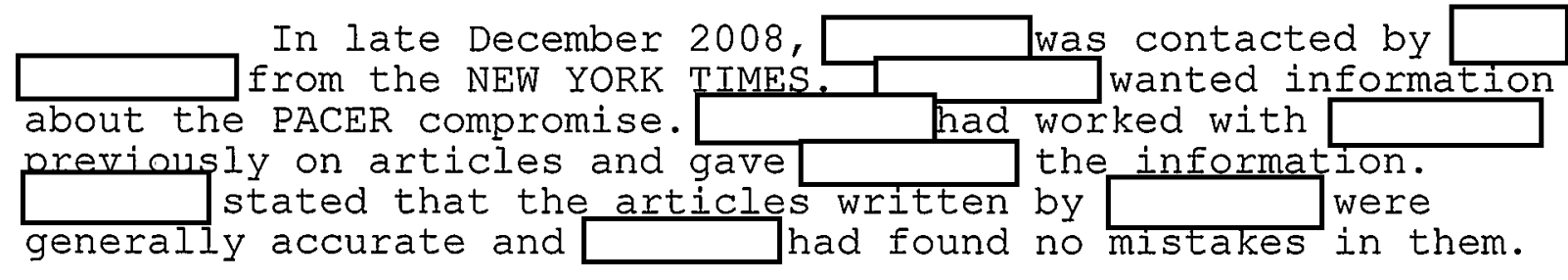

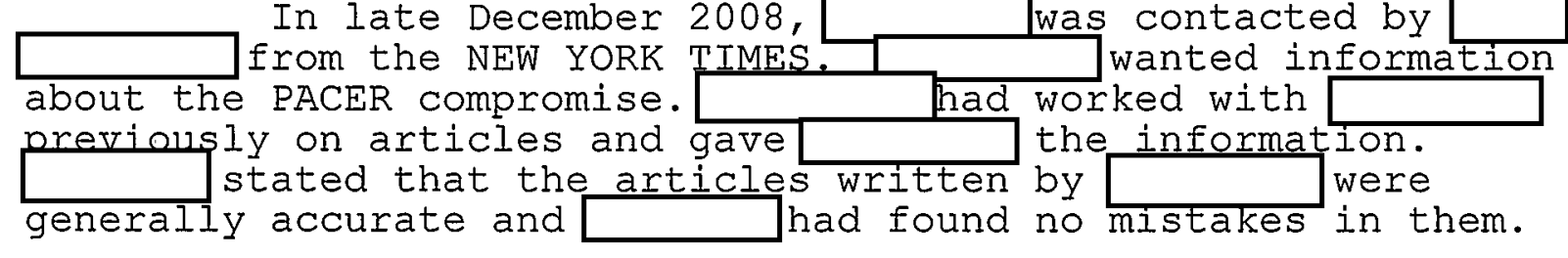
currently has a request before Judge LAMBERTH for a no fee exemption for PACER. With a no fee exemption, 